Dr MILAN GULIĆ, viši naučni saradnik

Institut za savremenu istoriju

Beograd, Republika Srbija

UDK 323(=163.41)(497.5)"1991/1992"

milan.gulic@gmail.com

323(497.1-89)"1991/1992"

originalan naučni rad / original scientific paper

primljeno / received: 30. 9. 2020.

prihvaćeno / accepted: 20. 11. 2020.

https://doi.org/10.29362/ist20veka.2021.1.gul.153-174

\title{
PARALELNA VLADA RISTE MATKOVIĆA 1992. PRILOG PROUČAVANJU POLITIČKIH SUKOBA U REPUBLICI SRPSKOJ KRAJINI
}

APSTRAKT: Prerastanje Srpske autonomne oblasti Krajine u Republiku Srpsku Krajinu bilo je praćeno međunarodnim pritiscima radi prihvatanja plana američkog diplomate Sajrusa Vensa i otpočinjanja mirovne operacije Ujedinjenih nacija, ali i pritiscima vlasti u Beogradu na rukovodstvo srpskih institucija u Kninu. Takva atmosfera dovela je i do značajnih političkih sukoba u Krajini. Smjenjivanje prvog predsjednika Republike Srpske Krajine Milana Babića i obaranje Vlade kojom je rukovodio, a zatim njegovo odbijanje da prihvati smjenu, doveli su do stvaranja „paralelne“ Vlade Krajine, na čije čelo je postavljen dotadašnji ministar pravosuđa i uprave Risto Matković. Vlada je potrajala svega nekoliko mjeseci, djelujući paralelno sa Vladom Zdravka Zečevića, i za to vrijeme nije ostvarila gotovo nikakav uticaj izvan Knina, u kojem su opštinske vlasti bile u rukama Milana Babića i njegovih političkih pristalica. Rad je zasnovan na arhivskoj građi, objavljenim dokumentima, štampi, relevantnoj literaturi i sjećanjima učesnika događaja.

KLJUČNE RIJEČI: Risto Matković, Republika Srpska Krajina, Vlada Republike Srpske Krajine, Skupština Republike Srpske Krajine, Milan Babić, Mile Paspalj

Politički problemi i kriza sistema koji su potresali Socijalističku Federativnu Republiku Jugoslaviju (SFRJ) doživjeli su kulminaciju na kraju osamdesetih godina 20. vijeka. Mitinzi solidarnosti sa srpskim narodom na Kosovu i Metohiji, serije štrajkova, tzv. antibirokratske revolucije, kojima su smijenjena rukovodstva u Crnoj Gori, na Kosovu i u Vojvodini, ustavne promjene i, konačno, slom Saveza komunista Jugoslavije (SKJ), kao jednog od nosećih stubova socijalističke jugoslovenske države, predstavljali su samo uvod u turobne devedesete godine 20. vijeka u kojima je ta država nestala. Pogoršane političke prilike naročito su se odrazile na međunacionalne odnose unutar Socijalističke Republike (SR) Hrvatske, gdje su nezaliječene rane iz vremena Drugog svjetskog 
rata $\mathrm{i}$ sve radikalnija retorika, naročito poslije prvih višestranačkih izbora na kojima je pobijedila Hrvatska demokratska zajednica (HDZ), prouzrokovali sve očigledniju netrpeljivost između Hrvata i Srba.

\section{Stvaranje srpske autonomije u Hrvatskoj i obrazovanje prve Vlade Krajine}

Pošto je Srpska demokratska stranka (SDS) na izborima koji su održani u drugoj polovini aprila i prvoj polovini maja 1990. osvojila lokalnu vlast u Kninu, Gračacu i Donjem Lapcu, nametnula se potreba za čvršćom saradnjom tih opština sa srpskom većinom. Budući da je Knin, prema tadašnjoj administrativnoj organizaciji SR Hrvatske, pripadao Zajednici općina Dalmacije, a Gračac i Donji Lapac Zajednici općina Like, odlučeno je da se formira Zajednica općina Sjeverne Dalmacije i Like. Svečano je proglašena na Dalmatinskom Kosovu 1. jula 1990. godine. Planirano je da Zajednica općina ima svoju skupštinu, a do njenog konstituisanja izvršni organ je bilo Privremeno predsjedništvo Skupštine Zajednice općina Sjeverne Dalmacije i Like. Upravo je to tijelo, na čijem čelu je bio predsjednik Skupštine općine (SO) Knin dr Milan Babić, predstavljalo zametak budućih krajinskih vlada. Ostali članovi Predsjedništva bili su predsjednici preostale dvije opštine članice Zajednice - David Rastović (Donji Lapac) i Vojislav Lukić (Gračac). ${ }^{1}$

Sabor SR Hrvatske usvojio je 25. jula 1990. amandmane na Ustav, koji su izazvali veliko nezadovoljstvo kod srpskog naroda u Hrvatskoj. Kao svojevrstan odgovor, Privremeno predsjedništvo Skupštine Zajednice općina Sjeverne Dalmacije i Like istog dana je organizovalo skup u Srbu (kod Donjeg Lapca). Aklamacijom je usvojena Deklaracija o suverenosti $i$ autonomiji srpskog naro$d a$, a obrazovani su: Srpski sabor, kao ,politički predstavnik srpskog naroda u Hrvatskoj", i Srpsko nacionalno vijeće (SNV), kao njegov izvršni organ. Srpsko nacionalno vijeće je predstavljalo razvijeniju varijantu Privremenog predsjedništva, a konstitutivnu sjednicu je održalo u Kninu 31. jula 1990. Za predsjednika je imenovan predsjednik SO Knin dr Milan Babić, za potpredsjednike: predsjednik SO Donji Lapac David Rastović i predsjednik Jugoslavenske samostalne demokratske stranke (JSDS) mr Mile Dakić, a za sekretara Dušan Vještica. Članovi SNV-a su bili predsjednici opština sa srpskom većinom, saborski zastupnici iz redova SDS-a i predsjednici dvije političke partije osnovane od strane Srba u Hrvatskoj - SDS-a i JSDS-a. ${ }^{2}$ Iako zaduženja nisu bila podijeljena

1 Davor Pauković, prir., Uspon i pad „Republike Srpske Krajine“. Dokumentarni kronološki prikaz nastanka i propasti paradržave (Zagreb: Centar za politološka istraživanja, 2005), 68-69; Mate Rupić, ur., Republika Hrvatska i Domovinski rat 1990.-1995. Dokumenti, II, Dokumenti institucija pobunjenih Srba u Republici Hrvatskoj (1990.-1991.) (Zagreb: Hrvatski memorijalno-dokumentacijski centar Domovinskog rata, Slavonski Brod: Hrvatski institut za povijest - Podružnica za povijest Slavonije, Srijema i Baranje, 2007), 33-35.

${ }^{2}$ Srpsko nacionalno vijeće su, prema tome, činili: predsjednici opština - dr Milan Babić (Knin), mr Zdravko Zečević (Benkovac), Sergej Veselinović (Obrovac), Vojislav Lu- 
po resorima, SNV je predstavljao ,,prvu srpsku vladu“ u Hrvatskoj, kako su je nazivali neki od savremenika. ${ }^{3}$

U narednim mjesecima Srbi u Hrvatskoj su, na osnovu izjašnjavanja koje je održano od 19. avgusta do 2. septembra 1990, proglasili autonomiju ,na etničkim i istorijskim teritorijama koje se nalaze unutar sadašnjih granica Republike Hrvatske kao federalne jedinice SFRJ“. Sa druge strane, nove hrvatske vlasti prionule su izradi novog Ustava Republike Hrvatske (RH). Kada se u javnosti pojavio nacrt novog Ustava, a u kontekstu zaoštrene međunacionalne situacije u Hrvatskoj, srpski politički predstavnici su odlučili da obrazuju teritorijalnu autonomiju. Na sjednici Privremenog predsjedništva Skupštine Zajednice općina Sjeverne Dalmacije i Like u Kninu 19. decembra 1990. usvojen je Statut Srpske autonomne oblasti (SAO) Krajina i poslat na usvajanje opštinama članicama Zajednice. ${ }^{4}$ Pošto je Statut sutradan usvojen od strane vlasti u Kninu, Benkovcu, Obrovcu, Gračacu, Donjem Lapcu, Titovoj Korenici i Vojniću, 21. decembra 1990. u Kninu je održana zajednička sjednica Privremenog predsjedništva Zajednice općina Sjeverne Dalmacije i Like i Srpskog nacionalnog vijeća, na kojoj je proglašena Srpska autonomna oblast Krajina. ${ }^{5}$

Statutom je predviđeno da oblasni organi budu Skupština i Izvršno vijeće. Sve dok se članovi Skupštine i Izvršnog vijeća ne izaberu u skladu sa Statutom, ulogu Skupštine SAO Krajine privremeno su obavljale skupštine opština udruženih u Zajednicu općina Sjeverne Dalmacije i Like. Privremeno predsjedništvo Skupštine Zajednice općina trebalo je da obavlja funkciju Izvršnog vijeća, a predsjednik Privremenog predsjedništva dužnost predsjednika Izvršnog vijeća. S obzirom na razbuktavanje rata prilike su se usložnjavale, pa je Skupština SAO Krajine konstituisana 30. aprila 1991. kada je svaka od opština iz njenog sastava delegirala po sedam poslanika. Za prvog predsjednika Skupštine izabran je Velibor Matijašević, dok su potpredsjednici postali Zdravko Zečević i Ilija Đukić. Takođe, Skupština je izabrala dr Milana Babića za predsjednika

kić (Gračac), David Rastović (Donji Lapac), Velibor Matijašević (Glina), Simo Rajšić (Dvor na Uni) i Slavko Dokmanović (Vukovar); zastupnici SDS-a u Saboru Republike Hrvatske - Jovan Opačić (Knin), Dušan Zelenbaba (Knin), Radoslav Tanjga (Knin), Ratko Ličina (Gračac), i Dušan Ergarac (Donji Lapac); predstavnici političkih stranaka - dr Jovan Rašković (SDS) i mr Mile Dakić (JSDS); kao i predstavnik Srpske pravoslavne crkve - sveštenik Savo Bosanac (Pakrac).

${ }^{3}$ Срђан Радуловић, Судбина Крајине (Београд: Дан граф, 1996), 18-19, 123-124; Миле Паспаљ, Албум из Крајине (Сарајево: МНИПТ Јавност, 1996), 52-53; Nikica Barić, Srpska pobuna u Hrvatskoj 1990.-1995. (Zagreb: Golden marketing, Tehnička knjiga, 2005), 72-75; M. Rupić, Dokumenti, II, 39-44, 47-56; Миле Паспаљ, Разоткривање истине (Београд: Културна заједница Крајине, 2015), 87-89.

${ }^{4} \mathrm{Na}$ sjednici su bili predsjednici devet opština članica Zajednice: Milan Babić (Knin), Zdravko Zečević (Benkovac), Sergej Veselinović (Obrovac), Jasminka Mandić (Gračac), David Rastović (Donji Lapac), Boško Božanić (Titova Korenica), Miloš Vučković (Vojnić), Velibor Matijašević (Glina) i Simo Rajšić (Dvor na Uni).

${ }_{5}^{5}$ М. Паспаљ, Албум из Крајине, 55-59; N. Barić, n. d., 94-95; D. Pauković, n. d., 7378; M. Rupić, Dokumenti, II, 120-124; М. Паспаљ, Разоткривање истине, 89-94. 
Izvršnog vijeća Skupštine SAO Krajine. Skupština je na svojoj Trećoj sjednici, koja je održana 29. maja 1991, donijela odluku kojom je Statut proglašen Ustavnim zakonom SAO Krajine. Takođe, usvojen je Zakon o Vladi Srpske Autonomne Oblasti Krajina, kojim je Izvršno vijeće Skupštine preimenovano u Vladu, a predsjednik Izvršnog vijeća Skupštine postao je predsjednik Vlade. ${ }^{6}$

Dana 29. maja 1991. formirana je prva Vlada Srpske autonomne oblasti Krajina, na čijem čelu je bio dr Milan Babić. Za potpredsjednika Vlade i ministra za prosvjetu, kulturu i fizičku kulturu imenovan je Dušan Starević, a za ostale članove: Risto Matković, potpredsjednik Vlade i ministar za pravosuđe i upravu; Jovan Radulović, ministar spoljnih poslova; Veljko Stoisavljević, ministar poljoprivrede, šumarstva, vodoprivrede, turizma i trgovine; Branko Šimpraga, ministar za saobraćaj i veze; Dušan Badža, ministar obrazovanja; dr Vaso Ležaić, ministar za zdravstvo, socijalni rad i socijalnu politiku; Lazar Macura, ministar za informisanje; i Petar Štikovac, ministar vjera. Zakon o Vladi Srpske Autonomne Oblasti Krajina proglašen je 31. maja 1991, čime je Vlada SAO Krajine i formalno utemeljena kao organ izvršne vlasti. Istog dana je proglašen i Zakon o ministarstvima Srpske Autonomne Oblasti Krajina, kojim je određeno da poslove uprave „obavljaju ministarstva i organi uprave u sastavu ministarstava“. 7 Predviđeno je osnivanje 15 resora, a u vrijeme formiranja Vlade popunjeno je devet. Još pet resora popunjeno je 27. juna 1991. Tada su članovi prve Vlade Krajine postali: Jovan Katić, potpredsjednik Vlade i ministar za industriju i ekonomski razvoj; Milan Martić, ministar unutrašnjih poslova; Vukašin Babić, ministar za elektroprivredu i energetiku; Milan Bauk, ministar finansija; i Dušan Vještica, ministar za urbanizam, stambeno-komunalne djelatnosti i građevinarstvo. ${ }^{8}$ Konačno, 21. novembra 1991. imenovan je posljednji

6 „Рјешење о избору предсједника Скупштине Српске Аутономне Области Крајина“, „Рјешење о избору два подпредсједника Скупштине Српске Аутономне Области Крајина“, „Рјешење о избору предсједника Извршног вијећа Скупштине Српске Аутономне Области Крајина“, Гласник Крајине, 17. 5. 1991, 122; M. Rupić, Dokumenti, II, 117-118, 165, 178-181; N. Barić, n. d., 101, 104; D. Pauković, n. d., 89-95.

7 „Указ о проглашењу Закона о Влади Српске Аутономне Области Крајина“, „Указ о проглашењу Закона о министарствима Српске Аутономне Области Крајина“, „Рјешење о избору подпредсједника Владе“, „Рјешење о избору министра спољних послова Српске Аутономне Области Крајине“, „Рјешење о избору министра за правосуђе и управу Српске Аутономне Области Крајине“, „Рјешење о избору министра пољопривреде, шумарства, водопривреде, туризма и трговине Српске Аутономне Области Крајине“, „Рјешење о избору министра за саобраћај и везе Српске Аутономне Области Крајине“, „Рјешење о избору министра образовања Српске Аутономне Области Крајине“, „Рјешење о избору министра за просвјету, културу и физичку културу Српске Аутономне Области Крајине“, „Рјешење о избору министра за здравство, социјални рад и социјалну политику САО Крајине“, „Рјешење о избору министра за информисање Српске Аутономне области Крајине“, „Рјешење о избору министра вјера“, Гласник Крајине, 5. 6. 1991, 177-181, 188-189.

8 „Рјешење о избору подпредсједника Владе“, „Рјешење о избору министра унутрашњих послова Српске Аутономне Области Крајина“, „Рјешење о избору ми- 
član prve Vlade Krajine - ministar odbrane potpukovnik Milan Tarbuk. Međutim, Vlada tada nije kompletirana, pošto je Dušan Starević razriješen dužnosti potpredsjednika Vlade i ministra za prosvjetu, kulturu i fizičku kulturu. ${ }^{9}$

\section{Vensov plan kao povod za rasplamsavanje političkih sukoba u Krajini}

Pod uticajem protjerivanja većine srpskog stanovništva sa područja Zapadne Slavonije, kao i žestokih borbi koje su se vodile oko Vukovara, „krnje“ Predsjedništvo SFRJ zatražilo je od Organizacije ujedinjenih nacija (OUN) 9. novembra 1991. upućivanje mirovnih snaga u Jugoslaviju, „u granični pojas između teritorija koje su nastanjene većinskim srpskim stanovništvom i teritorija čiji su stanovnici u većini hrvatske nacionalnosti““. Nekoliko dana kasnije zahtjev za angažovanje mirovnih snaga UN separatno je poslao i predsjednik Predsjedništva Stjepan Mesić, s tom razlikom što je tražio njihov razmještaj na granici između Hrvatske i Srbije. Pokretanje mirovne inicijative otvorilo je potpuno novo poglavlje u raspletu jugoslovenske krize. Zahtjev zvaničnog Beograda da se u Jugoslaviju upute mirovne snage imao je za cilj pokušaj da se zaustavi razbuktali konflikt, ali i da se težište rješenja krize prebaci sa Evropske zajednice (EZ) na Ujedinjene nacije, tj. iz Brisela u Njujork. To se najbolje vidjelo u riječima potpredsjednika Predsjedništva SFRJ dr Branka Kostića, koji je istakao da angažovanje mirovnih snaga UN ,ne samo da otvara šansu i mogućnost uspostavljanja mira i traženja političkog rješenja u mirnim uslovima, nego - po našoj ocjeni daje nama šansu da se izvučemo iz tih kandži Evropske zajednice, sa dominantnim uticajem njemačkog bloka; daje nam šansu za jače angažovanje Savjeta bezbjednosti za neposredniji i jači uticaj Sjedinjenih Američkih Država, kao i Sovjetskog Saveza u odnosu na Evropsku zajednicu i Njemačku“. Drugim riječima, ,angažovanje mirovnih snaga Ujedinjenih nacija predstavlja veoma uspešnu branu takvoj agresivnoj njemačkoj politici na ovom području“. Poslije više posjeta zaraćenoj Jugoslaviji, plan angažovanja mirovnih snaga izradio je lični izaslanik generalnog sekretara UN Havijera Pereza de Kueljara američki diplomata Sajrus Vens. Iako je ukazala na neke dijelove plana, koji nisu bili zadovoljavajući,

нистра за електропривреду и енергетику Српске Аутономне Области Крајине“, „Рјешење о избору министра за индустрију и економски развој Српске Аутономне Области Крајине“, „Рјешење о избору министра финансија Српске Аутономне области Крајине“, „Рјешење о избору министра за урбанизам, стамбенокомуналне дјелатности и грађевинарство“, Гласник Крајине, 2. 7. 1991, 204-205.

${ }^{9}$ Hrvatski memorijalno-dokumentacijski centar Domovinskog rata (HMDCDR), fond 3, Skupština Republike Srpske Krajine, kutija 1, Odluka o izboru ministra odbrane Srpske Autonomne Oblasti Krajine; HMDCDR, 3-1, Odluka o razrješenju dužnosti podpredsjednika Vlade Srpske Autonomne Oblasti Krajine; „Одлука о разрјешењу министра за просвјету, културу и физичку културу Српске Аутономне Области Крајине“, Гласник Крајине, 22. 11. 1991, 396; N. Barić, n. d., 145-146; Slaven Ružić, Djelovanje „,Vlade Republike Srpske Krajine“ 1991.-1995. (Zagreb: Hrvatski memorijalno-dokumentacijski centar Domovinskog rata, 2017), 25-29. 
Hrvatska je istakla da „nema bitnih primjedbi na izneseni plan primjene i funkcije mirovnih snaga OUN“. Zvanična Srbija je zatražila da se mirovne snage rasporede na tlu sve tri srpske autonomne oblasti u Hrvatskoj. Možemo reći da plan nije u potpunosti zadovoljio ni hrvatske ni srbijanske vlasti, ali im je bio koliko-toliko prihvatljiv. Međutim, jedan od glavnih preduslova za pokretanje mirovne operacije bio je da angažovanje mirovnih snaga prihvate "svi kojih se to tiče“. S obzirom na to da nije bila zadovoljna ponuđenim „konceptom moguće mirovne operacije“, SAO Krajina, tj. njeno rukovodstvo oličeno u predsjedniku Vlade Milanu Babiću, postala je glavna prepreka za realizaciju tzv. Vensovog plana. ${ }^{10}$

Uslijed sve snažnijih spoljašnjih, ali i unutrašnjih pritisaka, Milan Babić je odlučio da pokuša da ojača svoju poziciju. Prateći poteze EZ u pogledu priznanja jugoslovenskih republika za nezavisne države, inicirao je proglašenje Republike Srpske Krajine (RSK) 19. decembra 1991. Republika Srpska Krajina je proglašena na sjednici Skupštine SAO Krajine u Kninu, kao i na zasjedanju Velike narodne skupštine Srpske oblasti (SO) Slavonija, Baranja i Zapadni Srem u Borovu Selu. Tada je usvojen Ustav Republike Srpske Krajine, kojim je ona definisana kao „nacionalna država srpskog naroda i svih naroda koji u njoj žive“, a „teritoriju Srpske Krajine čini teritorija Srpske Autonomne Oblasti Krajina“. ${ }^{11}$ Za prvog predsjednika RSK odabran je Milan Babić, koji se našao i na čelu prve Vlade, budući da je krajinski politički sistem zamišljen kao predsjednički. Prva Vlada RSK predstavljala je samo preimenovanu dotadašnju Vladu SAO Krajine. Prerastanje autonomne oblasti u republiku trebalo je da ojača poziciju Krajine pred nastavak pregovora o slanju mirovnih snaga, kao i da osnaži rukovodstvo u Kninu. Krajinsko rukovodstvo je na taj način željelo da parira Hrvatskoj, koja je išla prema međunarodnom priznanju, za šta joj je vjetar u leđa dao Savjet ministara EZ 17. decembra usvajanjem Deklaracije o Jugoslaviji i Deklaracije o smjernicama za priznavanje novih država u Istočnoj Evropi i Sovjetskom Savezu. Evropska zajednica je tako iskazala spremnost da prizna nove države koje su se, „slijedeći istorijske promjene u regionu“, konsti-

${ }^{10}$ HMDCDR, fond 4, Vlada Republike Srpske Krajine, kutija 4, Stavovi Vlade Srpske autonomne oblasti Krajina povodom inicijative Predsjedništva SFRJ za angažovanje mirovnih snaga Ujedinjenih nacija; „Плави шлемови на границама Крајина“, Политика, 10. 11. 1991, 1-2; M. Rupić, Dokumenti, II, 272-275, 296-351; Ivica Miškulin, ,Republika Hrvatska i mirovna operacija Ujedinjenih naroda: kada, kako i zašto je došlo do njezine realizacije?", Historijski zbornik, LXIV, br. 1, (2011), 121-159; Goran Mladineo, ur., Tuđmanov arhiv. Korespondencija predsjednika Republike Hrvatske dr. Franje Tuđmana od 1990. do 1999. godine, I, Godine stvaranja i obrane: 1990.-1991. (Zagreb: Hrvatska sveučilišna naklada, Hrvatski institut za povijest, 2015), 490-491, 494-499; Милан Гулић, „Проглашење Републике Српске Крајине: у сјенци Венсовог плана“, у: Грађански рат у Хрватској 1991-1995, XI-XII, ур. Милојко Будимир (Београд: Удружење Срба из Хрватске, Српско културно друштво Зора, Српска читаоница Др Јован Рашковић, 2016), 274-337.

11 „Одлука о проглашењу Устава Републике Српске Крајине“, Службени гласник Републике Српске Крајине, 2. 1. 1992, 1-11; D. Pauković, n. d., 114-133; M. Rupić, Dokumenti, II, 356-376. 
tuisale na demokratskoj osnovi, prihvatile odgovarajuće međunarodne obaveze i obavezale se da sarađuju u mirovnom procesu putem pregovora. Sve dotadašnje jugoslovenske republike pozvane su da se do 23. decembra 1991. izjasne da li žele da budu priznate kao nezavisne države i da potvrde da su prihvatile sve postavljene uslove. Uz Sloveniju, Hrvatsku, Bosnu i Hercegovinu (BiH) i Makedoniju, zahtjeve su uputili RSK i Kosovo, ali oni nisu uzeti u razmatranje, uz objašnjenje da je poziv upućen samo ,postojećim republikama“. ${ }^{2}$

U posljednjim danima 1991. Sajrus Vens je dobio pristanak za plan mirovne inicijative od Predsjedništva SFRJ, predsjednika Republike Srbije Slobodana Miloševića i predsjednika Republike Hrvatske dr Franje Tuđmana. Tada je bilo sasvim jasno da vlast u Kninu postaje jedina brana ostvarenju onoga na šta su pristali zvanični Beograd i Zagreb. Kada je 3. januara 1992. došlo do sukoba između Predsjedništva SFRJ i predsjednika Skupštine RSK Mile Paspalja na Konvenciji o novoj Jugoslaviji, koja je održana u zgradi Skupštine SFRJ, bilo je sasvim očigledno da je Vensov plan postao kamen spoticanja u odnosima između Beograda i Knina. Sukob je izašao na vidjelo 8. januara, kada je u beogradskoj štampi objavljeno pismo u kojem predsjednik Milošević otvoreno kritikuje predsjednika Babića. Optužio ga je da se oglušio „o izričite stavove“ Predsjedništva SFRJ i rukovodstva Republike Srbije „dajući sebi za pravo“, kako je stajalo u pismu, da donosi odluke „čiji račun, nažalost, i u krvi treba da plaća čitav srpski narod“. U otvorenom pismu predsjednik Milošević je poručio da ,građani Krajine treba da znaju da ste svojim postupcima izgubili svako naše poverenje i da u buduće za odnose sa vlastima Republike Srbije moraju delegirati ljude kojima će narodni interes biti iznad ličnog političkog prestiža“. Na taj način je narod Krajine pozvan da smijeni svoje rukovodstvo, kako bi i dalje mogao da računa na pomoć i podršku iz Srbije. ${ }^{13}$

12 „Пет питања Е3 југословенским републикама“, „Пет захтева Е3 за признавање нових држава“, „Декларација ЕЗ“, „Декларација о Југославији“, Политика, 18. 12. 1991, 1-2; Д. Стевановић и М. Четник, „Проглашена Република Српска Крајина“, Политика, 20. 12. 1991, 11; „Проглашена Република Српска Крајина“, Српски глас, 29. 12. 1991, 1; „Рођена Република Српска Крајина“, Српска Нова ријеч, 31. 12. 1991, 1; Momir Stojković, prir., Balkanski ugovorni odnosi 1876-1996. Dvostrani i višestrani međunarodni ugovori i drugi diplomatski akti o državnim granicama, političkoj $i$ vojnoj saradnji, verskim i etničkim manjinama, III (1946-1996) (Beograd: Službeni list SRJ, Međunarodna politika, 1999), 523-526; Славољуб Шушић, Златоје Терзић и Никола Петровић, прир., Зборник докумената из области одбране и безбедности Југославије 1990-1991. године (Београд: Генералштаб Војске Југославије, Сектор за школство, обуку, научну и издавачку делатност, Управа за научну и издавачку делатност, 2002), 588-590; М. Гулић, н. д., 298-303.

13 „Прихваћен Венсов план о плавим шлемовима“, Политика, 3. 1. 1992, 2; Биљана Чпајак и Бранислав Радивојша, „Договор о новој Југославији“, Политика, 4. 1. 1992 , 5-6; Слободан Милошевић, „Народ не треба да подноси жртве због самољубља ни једног политичара“, Политика, 9. 1. 1992, 1; Момир Лазић, „Не дамо нашу Крајину“, Српске новине, 14. 1. 1992, 14; „Крајње неодговоран чин“, „Оспоравам вашу произвољну оптужбу“, Српска Нова ријеч, 20. 1. 1992, 2-3; N. Barić, n. d., 151-152; Mate Rupić, ur., Republika Hrvatska i Domovinski rat 1990.-1995. Dokumenti, IV, Do- 
Razmjena pisama na relaciji Milošević-Babić pokazala je dubinu neslaganja Beograda i Knina u pogledu pokretanja mirovne operacije, ali i „opasnu“ inicijativu za samostalnim djelovanjem i odlučivanjem krajinskih vlasti, kako je to doživljeno u vladajućim krugovima u Beogradu. Ni snažan pritisak iz Beograda, kao ni dolazak podsekretara UN Maraka Guldinga u Knin 27. januara nisu doveli do promjene stava u pogledu Vensovog plana. Uprkos izuzecima, kakvi su bili ministar unutrašnjih poslova Milan Martić i predsjednici opština Korenica i Donji Lapac - Boško Božanić i David Rastović, činilo se da je rukovodstvo Krajine jedinstveno na svim nivoima (od predsjednika Republike do predsjednika opština) i odlučno da ne prihvati takav plan. Kako bi se stav krajinskog rukovodstva konačno slomio, sazvana je sjednica Predsjedništva SFRJ u proširenom sastavu. Maratonsko zasjedanje, koje je počelo 31. januara, a završilo se 2. februara 1992, proteklo je u dugim monolozima, sporadičnim prepirkama, suprotstavljenim stavovima i sukobima na ivici fizičkog obračuna. Predstavnici SAO Zapadna Slavonija još ranije su izjavili da prihvataju Vensov plan, s obzirom na to da je njime bio obuhvaćen veći dio regije nego što je kontrolisala srpska strana. Po završetku zasjedanja, predsjednik Vlade SO Slavonija, Baranja i Zapadni Srem Goran Hadžić izjavio je da može ,posle svih ovde možda neopravdanih, ali i dosta opravdanih izgovorenih teških reči, prihvati plan kakav jeste". Uvidjevši da su stavovi Knina i Beograda nepomirljivi, predsjednik Babić je napustio zasjedanje u Palati federacije na Novom Beogradu. Takav njegov gest je iskorišćen, pa je Vensov plan prihvatio predsjednik Skupštine RSK Mile Paspalj. ${ }^{14}$

Takav potez predsjednika Skupštine i okretanje leđa predsjedniku RSK predstavljali su svojevrsni paradoks krajinske politike, budući da je upravo Milan Babić postavio Milu Paspalja na to mjesto u prethodnom, doista manjem sukobu unutar krajinskog rukovodstva. Tim gestom otpočeo je slom Milana Babića, pošto je Mile Paspalj, uz podršku iz Beograda, povukao odlučne poteze u cilju prihvatanja plana mirovne operacije i smjene vlasti u Kninu. Poslije ,postizanja saglasnosti“، o angažovanju mirovnih snaga, pod snažnim uticajem beogradskih elektronskih i štampanih medija, Vensov plan je imao sve više pristalica u Krajini, a Milan Babić sve manje. Plan su redom prihvatale opštine: Korenica, Glina, Vrginmost, Petrinja i Gračac. Vlada RSK, kojom je rukovodio Milan Babić, zasjedala je u ,krnjem“ sastavu 6. i 7. februara 1992. Izvršena je detaljna analiza

kumenti institucija pobunjenih Srba u Republici Hrvatskoj (siječanj-lipanj 1992) (Zagreb: Hrvatski memorijalno-dokumentacijski centar Domovinskog rata, Slavonski Brod: Hrvatski institut za povijest - Podružnica za povijest Slavonije, Srijema i Baranje, 2008), 6-11; М. Паспаљ, Разоткривање истине, 164-166; М. Гулић, н. д., 305-311.

${ }^{14}$ International Criminal Tribunal for the former Yugoslavia (ICTY), IT-02-54: Milosevic, Slobodan, Informacija o sastanku između dr Milana Babića i gospodina Guldinga; Милан Четник, „За сада без договора“, Политика, 28. 1. 1992, 1-2; С. Кљакић, „Напето и напорно заседање“, Политика, 3. 2. 1992, 2; Раде Ранковић, „Како је протекло 40 сати у Палати федерације“, Политика, 4. 2. 1992, 6; М. Паспаљ, Албум из Крајине, 122-126; N. Barić, n. d., 153-155; M. Rupić, Dokumenti, IV, 2945, 69-71; М. Паспаљ, Разоткривање истине, 168-173; М. Гулић, н. д., 311-321. 
događaja na sjednici Predsjedništva SFRJ, pokrenuta inicijativa da se održi referendum na kojem bi se narod Krajine izjasnio o Vensovom planu, a od Mile Paspalja je zatraženo da sazove sjednicu Skupštine za 10. februar u Kninu. Budući da se plašio da je izgubio većinu u Skupštini, Milan Babić i njegova Vlada donijeli su Zakon o privremenoj teritorijalnoj organizaciji Republike Srpska Krajina, na temelju kojeg su formirane nove opštine, i Uredbu o načinu vršenja poslova ministarstva i posebnih organizacija van njihovog sedišta, kojom je Krajina podijeljena na četiri okruga - Sjevernodalmatinski, Lički, Kordunski i Banijski. Zatraženo je da se odmah verifikuju mandati poslanika iz šest novih opština (Smoković - Zemunik Gornji, Bratiškovci - Skradin, Petrovo Polje - Drniš, Vrlika, Medak - Istočni Gospić i Teslingrad). Kako je svaka opština u Skupštinu RSK slala po sedam poslanika, na ovaj način je dobijao 42 odana poslanika. ${ }^{15}$

Kako bi Vensov plan bio formalno prihvaćen u RSK, Mile Paspalj je zakazao sjednicu Skupštine za 9. februar 1992. u Spomen-domu u Glini. Na zasjedanju je bilo prisutno 87 od ukupno 119 poslanika iz 17 krajinskih opština. Skupština je većinom glasova usvojila Vensov plan (81 poslanik za i šestoro uzdržanih), a otvoreno je i pitanje povjerenja predsjedniku i Vladi RSK. U kritikama su najdalje otišli jedan ministar u toj Vladi (Milan Martić) i jedan predsjednik opštine (Sergej Veselinović). Predsjednik Babić je poricao legalitet skupštinskog zasjedanja u Glini i odbijao da prihvati usvojene odluke. Štaviše, za 10. februar je zakazao zasjedanje Skupštine RSK u Kninu, čime je došlo do dvojstva zakonodavne vlasti u RSK. U prvoj polovini februara 1992. RSK je imala dvije skupštine - jednu u Kninu, koja je bila odana Milanu Babiću, a koju nije priznavao niko, a drugu u Glini, okupljenu oko Mile Paspalja, koja je imala podršku Beograda. Većinom su različiti ljudi bili poslanici u tim skupštinama, premda je bilo rijetkih koji su pokušali da učestvuju u radu obje. Većina dotadašnjih poslanika, međutim, priznavala je samo Skupštinu u Glini. S obzirom na odluku Vlade o formiranju šest novih opština, u Knin je trebalo da dođe 161 poslanik. Umjesto toga, došla su 42 poslanika iz novih opština i svega 26 dotadašnjih poslanika. Iz 10 krajinskih opština u Knin nije došao niti jedan poslanik (Okučani, Petrinja, Glina, Kostajnica, Vrginmost, Vojnić, Karlovac-Krnjak, Plaški, Korenica i Donji Lapac), zbog čega teško da je postignut kvorum. ${ }^{16}$

Bez obzira na to što je bio potpuno marginalizovan i ignorisan, kao aktuelni predsjednik RSK i Vlade RSK Milan Babić je imao, barem formalnu, težinu.

15 HMDCDR, 4-5, Zapisnik sa 23. sjednice Vlade RSK, održane dana 6.02.1992, u zgradi opštine, soba broj 51; Александар Кнежевић, „Тражи се референдум о Венсовом плану“, Политика, 8. 2. 1992, 7; N. Barić, n. d., 156-158; M. Rupić, Dokumenti, IV, 72-87; М. Гулић, н. д., 321-324.

${ }^{16}$ HMDCDR, 3-2, Odluka o verifikaciji mandata poslanika Skupštine RSK; Ђ. Ђукић, „Скупштина Крајине прихватила план“, „Постављено питање поверења др Милану Бабићу“, Политика, 10. 2. 1992, 1, 6; М. Четник, „Без кворума гласали за референдум“, Политика, 11. 2. 1992, 1; Ч. К., „Мировњаци долазе“, Српски глас, 6. 3. 1992, 5; D. Pauković, n. d., 181-188; N. Barić, n. d., 158-159; M. Rupić, Dokumenti, IV, 90-91, 93-99; М. Гулић, н. д., 324-327. 
Kako bi mu se jedino uporište oduzelo, za 16. februar 1992. sazvana je sjednica Skupštine RSK u Glini. Na prijedlog poslanika Sergeja Veselinovića i Dušana Ećimovića Skupština je raspravljala o povjerenju predsjedniku i Vladi RSK. Od 84 prisutna poslanika, za smjenjivanje prvog predsjednika RSK Milana Babića glasalo je 73, dok je nepovjerenje Vladi RSK iskazano sa samo jednim glasom protiv. Na taj način je, poslije nepuna dva mjeseca smijenjen prvi predsjednik RSK i oborena njena prva Vlada. Prema Ustavu RSK, Skupština je imala pravo da razrješava prvog ministra i ministre u Vladi. Pitanje je, međutim, da li je imala pravo da smjenjuje predsjednika. Ustav je propisivao da „kad Skupština ocijeni da je predsjednik Republike Srpske Krajine prekršio Ustav, pokreće postupak za njegov opoziv ako se o tome izjasni dvije trećine od ukupnog broja poslanika“. ${ }^{17}$ U skladu sa Ustavom, do izbora novog predsjednika tu dužnost je vršio predsjednik Skupštine, dok je „odlazeća“" Vlada ostala na dužnosti do izbora nove Vlade. Osim toga, donijeta je odluka da se što prije sazove ,zajednička Skupština Republike Srpske Krajine u njezinoj teritorijalnoj cjelovitosti“, tj. sa poslanicima iz Krajine, Zapadne Slavonije i Slavonije, Baranje i Zapadnog Srema. ${ }^{18}$

\section{Nastanak i djelovanje Vlade Riste Matkovića}

Odluke usvojene na zasjedanju Skupštine RSK u Glini smijenjeni Milan Babić nije prihvatio. U saopštenju njegove tada već tehničke Vlade navedeno je da u Glini nije bilo kvoruma, pošto je prisustvovalo samo 47 od 161 poslanika, zbog čega Vlada smatra da se ne radi o zasjedanju Skupštine RSK, već samo o neformalnom sastanku ,grupe poslanika Skupštine“. S tim u vezi, odluke donijete od strane ,grupe poslanika“ nisu se mogle smatrati punovažnim. Skup u Glini, kako je navedeno u saopštenju Vlade, ,„predstavlja pokušaj državnog udara, koji je imao za cilj da svrgne legalnog predsednika Republike Srpska Krajina i vladu Republike Srpska Krajina, da bi vlast vodila grupa ljudi koja hoće da Republiku Srpska Krajina vrati u nezavisnu državu Hrvatsku i time poništi svu njegovu borbu za slobodu i pogazi svete žrtve koje su pale za otadžbinu“. ${ }^{19}$

${ }^{17}$ Ustav je dalje precizirao: „O opozivu predsjednika Republike Srpske Krajine odlučuje se neposrednim i tajnim izjašnjavanjem. Predsjednik Republike Srpske Krajine je opozvan ako za opoziv glasa većina od ukupnog broja birača. Ako birači ne opozovu predsjednika Republike Srpske Krajine, Skupština se raspušta.“ Međutim, pošto Milan Babić za predsjednika nije izabran ,na neposrednim izborima, tajnim glasanjem“, kako je Ustav propisivao, već u Skupštini, onda je i njegova smjena unutar najvišeg zakonodavnog tijela u Republici bila logičan slijed događaja. „Одлука о проглашењу Устава Републике Српске Крајине“, Службени гласник Pепублике Српске Крајине, 2. 1. 1992, 1-11; M. Rupić, Dokumenti, II, 356-376.

18 Ђ. Ђ.,Ванредна седница Скупштине Републике Српска Крајина“, Политика, 16. 2. 1992, 7; Ђ. Ђукић, „Јуче у Глини разрешен дужности др Милан Бабић“, Политика, 17. 2. 1992, 1; Ч. Кораћ, „Разријешен дужности Милан Бабић“, Српски глас, 6. 3. 1992, 1; N. Barić, n. d., 159-160; M. Rupić, Dokumenti, IV, 103-115; М. Гулић, н. д., 328-329.

19 „Није било кворума“, „Бабић оспорио одлуке Скупштине“, Политика, 17. 2. 1992, 5; М. Гулић, н. д., 329-330. 
Osim saopštenja, odgovor je stigao i u formi održavanja zasjedanja „Babićeve" Skupštine u Kninu 18. februara 1992. Prisutno je bilo 83 poslanika, a kako bi zasjedanje dobilo na značaju, u sali su bili „odlazeći“ predsjednik Milan Babić, ministar u tehničkoj Vladi Risto Matković i predsjednik Vrhovnog suda Uroš Funduk. Pošto na zasjedanje nisu došli predsjednik i potpredsjednici Skupštine, dogovoreno je da predsjedavajući bude poslanik iz tek formirane opštine Bratiškovci-Skradin Milan Štrbac. Sav besmisao ovog sukobljavanja i dvojstva odmah je razobličio poslanik iz Knina Tihomir Medić. Predložio je da se dvije krajinske skupštine sastanu i ,iskristališu stavove, jer ne može više jedna skupština da negira stavove druge“. Naveo je da bi tokom iduće nedjelje trebalo sazvati vanredno zasjedanje Skupštine RSK. Svi njegovi prijedlozi, međutim, glatko su odbačeni. $\mathrm{Na}$ isti način se većina prisutnih ponijela i prema stavovima poslanika iz Vojnića Miloša Vučkovića, koji je napomenuo da je na zasjedanje Skupštine u Knin došao ,radi jedinstva srpskog naroda“ i da je zbog toga bio i na zasjedanju u Glini dva dana ranije. Održavanje zajedničke sjednice Skupštine RSK predložio je i poslanik iz Knina Gojko Torbica. Milan Babić je istakao da je nekoliko dana ranije bio na sastanku sa poslanicima Skupštine sa prostora Korduna, na kojem je bio i predsjednik Skupštine Paspalj. Dogovoreno je da se zajednička sjednica Skupštine održi u Slunju, ,kao geografskom centru Republike“, ali je Mile Paspalj odlučio da se zasjedanje održi u Glini i tu inicirao izglasavanje nepovjerenja predsjedniku i Vladi i time ,napravio pokušaj državnog udara i raskola u Krajini“. S obzirom na vanredne okolnosti, Milan Babić je predložio da se proglasi trajno zasjedanje Skupštine, a da poslanici dolaze ,po mogućnosti““ ${ }^{20}$

Bez obzira na to što je na sjednici Skupštine RSK u Glini smijenjen sa mjesta predsjednika i što je oborena Vlada kojom je rukovodio, a on ostao samo predsjednik SO Knin, Milan Babić je nastojao da i dalje utiče na politička zbivanja u čitavoj Krajini, podržavajući njemu odanu „Skupštinu RSK“. Trajno zasjedanje „Babićeve“ Skupštine u Kninu nastavljeno je 21. februara 1992, u prisustvu 84 poslanika. Koliko je atmosfera u krajinskoj politici bila zaoštrena ponovo se moglo vidjeti iz riječi poslanika Tihomira Medića. On je ukazao ,da su se poslanici Skupštine podijelili u dva tabora, a o jedinstvu sa Srbijom ne može više da se govori“. Iskazao je mišljenje da je Ustav RSK ,sve samo ne demokratski, jer nas je odvojio od matice Srbije i ostatka Jugoslavije“. Ne osvrćući se na ovakva izlaganja, „Babićeva“ Skupština je decidirano navela da ne priznaje odluke „skupa u Glini““ i donijela odluku o opozivu predsjednika Skupštine Mile Paspalja i potpredsjednika Ilije Đukića i Zdravka Zečevića. Za novog predsjednika imenovan je poslanik iz Dvora na Uni Petar Cvetanović, a za potpredsjednike Ratomir Ivaniš iz Benkovca i Milan Ivanić iz Sisak-Capraga. ${ }^{21}$

${ }^{20}$ HMDCDR, 3-2, Zapisnik sa 1. sjednice Prvog redovnog zasjedanja Skupštine RSK održane u Kninu, u opštinskoj vijećnici, dana 18.02.1992. godine; М. Гулић, н. д., 330-331.

${ }^{21}$ HMDCDR, 3-2, Zapisnik sa 1. sjednice Prvog redovnog zasjedanja Skupštine RSK, održane u opštinskoj vijećnici u Kninu, 21.2.1992, Odluka o razrješenju predsjednika Skupštine RSK, Odluka o razrješenju podpredsjednika Skupštine RSK, Odluka o izboru predsjednika Skupštine RSK, Odluka o izboru podpredsjednika Skupštine 


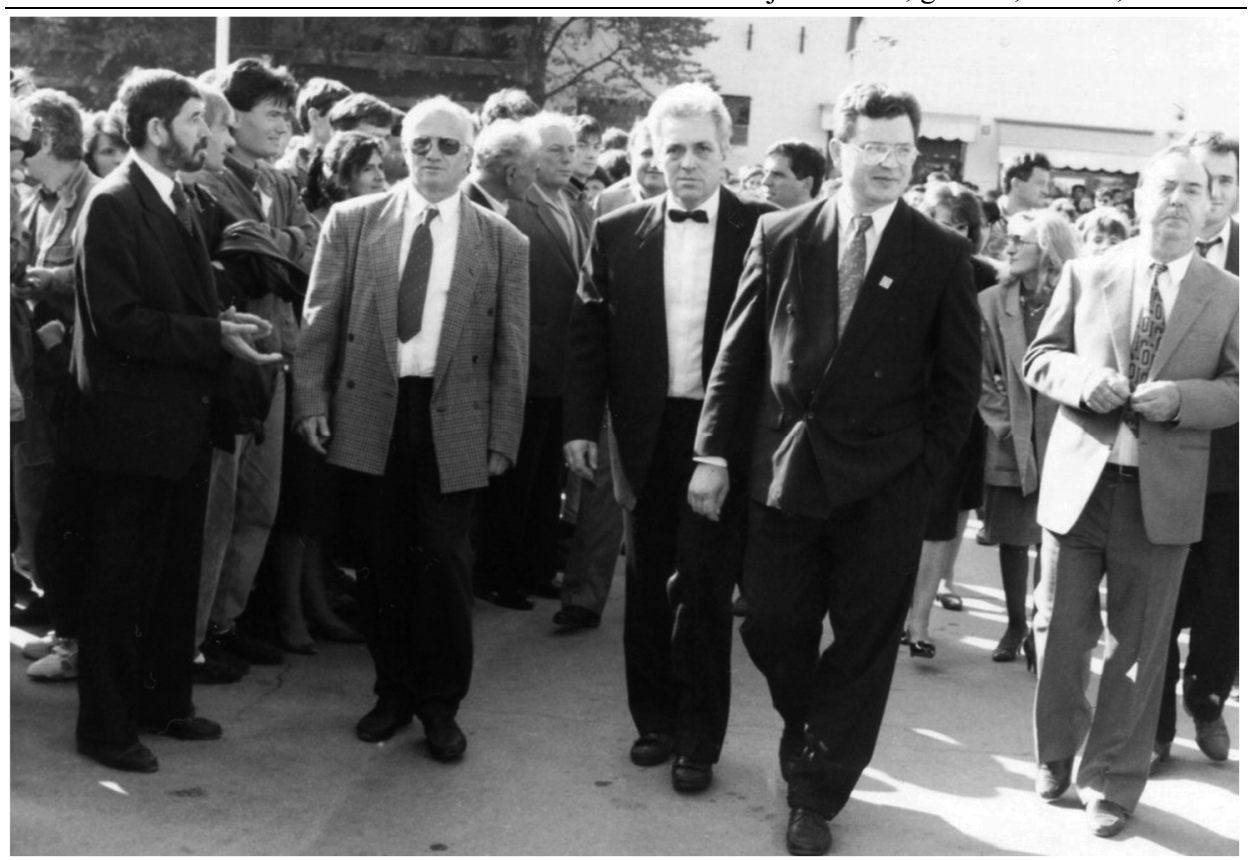

Vaso Ležajić, Risto Matković i Milan Babić u Kninu 1991. godine (Privatna zbirka Riste Matkovića)

Milan Babić je predložio i sastav nove Vlade RSK, a za prvog ministra imenovao Ristu Matkovića. ${ }^{22}$ Sastav njegove Vlade je bio takav da je zadržan dio ministara iz prethodne Vlade, dok su pojedini zamijenjeni ljudima odanim Milanu Babiću. Umjesto Milana Martića, za ministra unutrašnjih poslova je postavljen Slavko Ožegović, umjesto Jovana Radulovića ministar inostranih poslova je postao Borivoj Rašuo, umjesto Milana Bauka ministar finansija je postao Drago Jaramaz, dok je umjesto Branka Šimprage za ministra saobraćaja i veza imenovan Savan Grabundžija. Osim dužnosti prvog ministra, Risto Mat-

RSK; „Смењени Паспаљ и Мартић“, Политика, 22. 2. 1992, 7; N. Barić, $n . d$., $161 ;$ S. Ružić, $n$. d., 45.

${ }^{22}$ Risto Matković je rođen u Fojnici (kod Gacka) 23. decembra 1947. Osnovnu školu je završio u rodnom mjestu, gimnaziju u Mostaru, a Pravni fakultet u Sarajevu. Kratko je bio zaposlen u Preduzeću PTT saobraćaja u Sarajevu, a 1976. prešao je u Knin. Radio je u Elektri, Ciglani „Stevo Opačić“" u Strmici i Pravnoj službi Željezničkotransportnog poduzeća Knin, a zatim je imenovan za sudiju Općinskog suda u Drnišu. U vrijeme zaoštravanja međunacionalnih odnosa (1990) vratio se u Knin i postao sekretar, a zatim predsjednik Izvršnog vijeća SO Knin (1991). Poslije smjene sa premijerskog i ministarskog mjesta i uklanjanja iz opštinskih vlasti, imenovan je za predsjednika Okružnog suda u Kninu 9. juna 1993. Bio je savjetnik predsjednika RSK Milana Martića za pravna i vjerska pitanja. Od 1995. živi u Srbiji. Kratko se bavio advokaturom u Beogradu, a 1997. imenovan je za sudiju Opštinskog suda u Adi. Po napuštanju sudijske funkcije, posvetio se advokaturi. Kao penzioner živi u Adi. Intervju sa Ristom Matkovićem, Ada, Srbija, 18. 11. 2020. 
ković je nastavio da obavlja funkciju ministra za pravosuđe i upravu. Na svojim ministarskim mjestima ostali su Jovan Katić, kao ministar za industriju i ekonomski razvoj, Vukašin Babić, kao ministar za energetiku, Dušan Badža, kao ministar za obrazovanje, Mićo Jelić Grnović, kao ministar prosvjete, kulture i fizičke kulture, Vaso Ležaić, kao ministar za zdravlje, socijalni rad i socijalnu politiku, Lazar Macura, kao ministar informisanja i Petar Štikovac, kao ministar vjera. Izabrani su i načelnici okruga, koji su bili članovi Vlade u rangu ministara. Za načelnika Sjevernodalmatinskog okruga imenovan je Rajko Ležajić, za načelnika Ličkog okruga Dušan Vještica, za načelnika Kordunskog okruga Mile Bosnić, a za načelnika Banijskog okruga Branko Dmitrović. Iako izabrani za članove Vlade, neki od ovih ljudi nisu prisustvovali niti jednoj sjednici. Takav je slučaj sa ministrima Borivojem Rašuom, Savanom Grabundžijom kao i načelnicima okruga Milom Bosnićem i Brankom Dmitrovićem. ${ }^{23}$

Ova „Vlada RSK“, međutim, nije imala legitimitet, niti bilo kakvu efektivnu vlast. Legitimna nije mogla da bude pošto je Ustav RSK jasno propisivao da kandidate za članove Vlade imenuje predsjednik Republike, što Milan Babić u tom trenutku više nije bio, a bira Skupština, što takođe nije bio slučaj, pošto je većina poslanika Skupštine RSK zasjedala u Glini i donijela odluku o smjeni predsjednika i Vlade. Da Vlada neće imati nikakvu stvarnu vlast vidjelo se već na sastanku sekretara unutrašnjih poslova Banije i Korduna, kao i načelnika stanica javne bezbjednosti na tom području, koji je održan 24. februara u Glini. U saopštenju je navedeno: „Za svoj rad odgovaramo ministru unutrašnjih poslova Milanu Martiću i srpskom narodu. Ničije drugo rukovođenje ne priznajemo do izbora novog ministra na sednici Skupštine Republike Srpska Krajina koja je zakazana u Vukovaru 26. i 27. februara“. Bilo je sasvim jasno da su Banija i Kordun potpuno izvan vlasti Milana Babića, koga su smatrali samo predsjednikom kninske opštine. Osim na miliciju, Vlada Riste Matkovića nije mogla da računa ni na vojsku, tj. na Teritorijalnu odbranu (TO) RSK, budući da je ova bila čvrsto oslonjena na zvanični Beograd. ${ }^{24}$

Prva sjednica Vlade, kojom je predsjedavao Risto Matković, održana je 24. februara 1992. Radilo se o 27. sjednici Vlade RSK, čime je bilo jasno da ona predstavlja samo nastavak Vlade RSK i Vlade SAO Krajine, kojima je rukovodio Milan Babić. Sjednica je održana istog dana kada je Savjet bezbjednosti (SB) UN usvojio Rezoluciju 743, kojom je „mirovna operacija u Jugoslaviji praktično otpočela“. Uz

${ }^{23}$ HMDCDR, 3-2, Odluka o izboru prvog ministra u Vladi RSK, Odluka o izboru ministra Unutrašnjih poslova RSK, Odluka o izboru ministra spoljnih poslova RSK, Odluka o izboru ministra finansija RSK, Odluka o izboru ministra za pravosuđe i upravu RSK, Odluka o izboru ministra za industriju i ekonomski razvoj RSK, Odluka o izboru ministra za energetiku RSK, Odluka o izboru ministra za saobraćaj i veze RSK, Odluka o izboru ministra za obrazovanje RSK, Odluka o izboru ministra za prosvjetu, kulturu i fizičku kulturu RSK, Odluka o izboru ministra za zdravlje, socijalni rad i socijalnu politiku, Odluka o izboru ministra za informisanje RSK, Odluka o izboru ministra vjera RSK; N. Barić, $n$. d., 586-587; S. Ružić, $n$. d., 47-48.

24 Ђ. Ђ., „Признају само Мартића“, Политика, 25. 2. 1992, 9; N. Barić, n. d., 160 161; М. Гулић, н. д., 332-334; S. Ružić, n. d., 46, 49-50. 
prvog ministra Matkovića, prisutni su bili ministri Vaso Ležaić, Drago Jaramaz, Lazar Macura, Vukašin Babić, Jovan Katić, Petar Štikovac i Slavko Ožegović, kao i načelnici okruga Dušan Vještica i Rajko Ležajić. Na sjednici je bila uočljiva potpuna promjena odnosa prema Vensovom planu. Zaključeno je da su u vezi sa Vensovim planom „,usvojeni zahtjevi naše Vlade, jer se prema zadnjoj rezoluciji Ujedinjenih nacija zaštićena područja spominju kao dijelovi Jugoslavije“. Osim toga, kako je naveo premijer Matković, u dokumentima se više nisu spominjale „mirovne snage“, već „Zaštitne snage“, što bi značilo „da se sada Republika Srpska Krajina više ne tretira kao agresor već se tretira Republika Hrvatska, jer su snage zaštite na tim područjima“. Risto Matković je napomenuo da je Krajina naišla na više razumijevanja ,u Savjetu bezbjednosti Ujedinjenih nacija nego od strane nekih jugoslovenskih i srpskih političara“, i da su dodatne garancije dobijene ,,isključivo naporima RSK“, što je, kako je naveo, ,,dokaz ispravnosti našeg stava““.

Osim o pokretanju mirovne operacije, Vlada je raspravljala o tekućim pitanjima, zakonskim prijedlozima, rješenjima i odlukama. Premijer Matković je obavijestio članove Vlade da su „neke opštine obustavile uplaćivanje u Budžet Krajine“" zbog čega se budžet sveo na davanja iz opština Knin i Dvor na Uni. U isto vrijeme te opštine, kako je naveo, „traže novac za potrebe pravosuđa, školstva, zdravstva itd.“ Usvajanjem Zakona o lokalnoj samoupravi, Zakona o izboru poslanika u Skupštinu Republike Srpska Krajina i Zakona o izbornim jedinicama Vlada Riste Matkovića je nastojala da ozakoni promjene učinjene tokom borbi za prevlast na političkom nebu Krajine. Osim toga, usvojeni su: Zakon o radnim odnosima $u$ državnim organima, Zakon o pečatu državnih $i$ drugih organa, Zakon o socijalnoj zaštiti i obezbjeđivanju socijalne sigurnosti građana, Zakon o prevozu u putnom saobraćaju, Zakon o ličnoj karti, Zakon o političkim organizacijama, Zakon o elektroprivredi, Zakon o osnivanju Javnog preduzeća Krajina-petrol, Zakon o izmjeni i dopuni Zakona o stopama neposrednih poreza i pripadnosti poreza, taksa i drugih prihoda društveno-političkih zajednica u 1991. godini i Zakon o izmjeni i dopuni Zakona o neposrednim porezima. Usvojen je i Zakon o državljanstvu, prema kojem su građani RSK zadržavali državljanstvo Jugoslavije. Donijete su: Odluka o osnivanju Republičkog fonda penzionog $i$ invalidskog osiguranja, Odluka o naknadama $i$ drugim primanjima nosilaca pravosudnih funkcija i Odluka o naknadama i nagradama sudija porotnika, kao i uredbe: Uredba o kancelarijskom poslovanju, Uredba o stalnim sudskim tumačima i Uredba o radnom vremenu u privrednim i vanprivrednim subjektima na teritoriji Republike Srpska Krajina u ratnim uslovima. Vlada je donijela i nekoliko rješenja o postavljenju. Za vršioca dužnosti direktora tek osnovanog Javnog preduzeća (JP) Krajinapetrol, koje je preuzelo imovinu Industrije nafte (INA) iz Siska, koja je ostala na teritoriji Krajine, imenovan je potpredsjednik Izvršnog vijeća SO Knin Veljko Popović. Glavni cilj stvaranja tog javnog preduzeća bio je da Vlada Riste Matkovića pokuša da stavi pod svo-

${ }^{25}$ HMDCDR, 4-5, Zapisnik sa 27. sjednice Vlade Republike Srpska Krajina, održane 24.2.1992. godine u zgradi opštine, soba br. 51; M. Rupić, Dokumenti, IV, 129-136; М. Гулић, н. д., 334. 
ju kontrolu naftne rezerve i trgovinu naftnim derivatima. Imenovani su članovi Upravnog odbora Fonda zdravstvene zaštite i zdravstvenog osiguranja Republike Srpska Krajina i predsjednik i članovi Upravnog odbora Javnog željezničkog transportnog preduzeća. Na osnovu imenovanih lica vidimo da se radi o preduzećima sa ingerencijom samo na tlu dotadašnje SAO Krajine. ${ }^{26}$

Sutradan, 25. februara nastavljeno je trajno zasjedanje „Skupštine RSK“ u Kninu. Tada je verifikovano sedam novih poslaničkih mandata sa područja novoproglašene Opštine Udbina. Određen je sastav Ustavnog suda RSK, budući da je Vlada Riste Matkovića imala određeni uticaj u pravosuđu, pa je za predsjednika imenovan Milan Vučak iz Knina, a za sudije: Miloš Vučinić (Slunj), Radovan Štrbac (Knin) i Veljko Samardžija (Sisak-Caprag). Osim toga, imenovana su još dva ministra, čime je Vlada Riste Matkovića dobila pun sastav. Novi ministar za urbanizam, stambeno-komunalne djelatnosti i građevinarstvo postao je Veljko Popović (umjesto Dušana Vještice), dok je za novog ministra odbrane imenovan Miloš Pupavac (umjesto Milana Tarbuka). Ni jedan ni drugi nikada nisu prisustvovali sjednicama Vlade u kojoj su bili odgovorni za važne resore. ${ }^{27}$

Većina odluka Skupštine u Kninu, međutim, nije mogla da se sprovede na terenu. Sa druge strane, odluke sa Skupštine u Glini bilo je moguće realizovati. Tako je i najava da će se u najkraćem roku održati sjednica Skupštine RSK na kojoj bi bile zastupljene sve tri oblasti koje su tvorile Krajinu ubrzo ostvarena. Dana 26. februara 1992. u fiskulturnoj sali osnovne škole u Borovu Selu održana je Velika narodna skupština Srpske autonomne oblasti Krajina, Srpske oblasti Slavonija, Baranja i Zapadni Srem i Srpske autonomne oblasti Zapadna Slavonija. Na taj način je obrazovana prva jedinstvena Skupština RSK, koju je trebalo da čini 119 poslanika dotadašnje Skupštine SAO Krajina, 100 poslanika dotadašnje Velike narodne skupštine SO Slavonija, Baranja i Zapadni Srem i 63 poslanika dotadašnje Narodne skupštine SAO Zapadna Slavonija. Od 282 poslanika ukupno prisutno je bilo 236, od čega 97 iz Krajine, 93 iz Slavonije, Baranje i Zapadnog Srema i 46 iz Zapadne Slavonije. ${ }^{28}$

Na skupštinskom zasjedanju u Borovu Selu usvojene su važne odluke kojima je Republika Srpska Krajina u teritorijalnom i institucionalnom smislu u potpunosti zaokružena. Usvojeni su amandmani na Ustav, kojima je precizirano da teritoriju RSK čine tri oblasti: Krajina, Zapadna Slavonija i Slavonija, Bara-

${ }^{26}$ HMDCDR, 4-5, Zapisnik sa 27. sjednice Vlade RSK održane 24.2.1992. godine u zgradi opštine, soba br. 51; M. Rupić, Dokumenti, IV, 129-136; S. Ružić, n. d., 51$52,54-55$.

${ }^{27}$ HMDCDR, 3-2, Odluka o izboru predsjednika Ustavnog suda RSK, Odluka o izboru sudije Ustavnog suda RSK, Odluka o izboru ministra za urbanizam, stambeno-komunalne djelatnosti i građevinarstvo RSK, Odluka o izboru ministra odbrane RSK, Odluka o verifikaciji mandata poslanika Skupštine RSK; М. Гулић, н. d., 334; S. Ružić, n. d., 47, 50-51.

${ }^{28}$ HMDCDR, 3-2, Magnetofonske beleške sa sednice Skupštine SAO Krajine, AO Slavonija, Baranja, Zapadni Srem i AO Zapadna Slavonija, održane 26.02.1992. godine, u Borovu Selu; M. Rupić, Dokumenti, IV, 137-149; М. Паспаљ, Албум из Крајине, 138-142, 144-160; Исти, Разоткривање истине, 205-222. 
nja i Zapadni Srem. Takođe, uklonjena je teza da je RSK nastala tako što su se dvije oblasti pripojile Krajini i naglašeno da je RSK nastala ujedinjenjem tri srpske oblasti. Precizirano je da predsjednika Republike, prvog ministra i članove Vlade bira i razrješava Skupština. Po završetku rasprave o ustavnim amandmanima, predsjedavajući Ilija Končarević predložio je da se za novog predsjednika RSK izabere Goran Hadžić, dotadašnji predsjednik Vlade SO Slavonija, Baranja i Zapadni Srem. Većina prisutnih poslanika glasala je da Goran Hadžić postane drugi predsjednik RSK, iako je postojao prijedlog da na to mjesto bude postavljen profesor Pravnog fakulteta u Beogradu i bivši potpredsjednik Vlade Republike Srbije dr Budimir Košutić. ${ }^{29}$

Pošto je položio zakletvu, predsjednik Hadžić je obavio konsultacije sa predsjednicima krajinskih opština, kako bi se usaglasio prijedlog za mandatara za sastav prve jedinstvene Vlade RSK. Dogovoreno je da mandat za sastav nove Vlade bude povjeren predsjedniku SO Benkovac mr Zdravku Zečeviću. Skupština je podržala ovakav prijedlog sa samo jednim uzdržanim glasom. Zdravko Zečević je istog dana predstavio nepotpun sastav prve Vlade u kojoj su bili ministri iz svih dijelova RSK. Osam ministara je bilo iz Krajine, a po tri iz Zapadne Slavonije i Slavonije, Baranje i Zapadnog Srema. Među njima je bio i Savan Grabundžija, koji se nalazio na ministarskoj dužnosti i u Vladi Riste Matkovića. ${ }^{30}$ Poslije izbora članova Vlade, donijeta je odluka da, do izbora novog skup-

${ }^{29}$ HMDCDR, 3-2, Magnetofonske beleške sa sednice održane 26.02.1992. godine, u Borovu Selu; „Одлука о проглашењу амандмана I до VI на Устав Републике Српске Крајине“, „Одлука о проглашењу Уставног закона за спровођење амандмана на Устав Републике Српске Крајине“, Службени гласник Републике Српске Крајине, 27. 2. 1992, 13-15; Р. Суботић, С. Берић, „Хаџић уместо Бабића“, Политика, 27. 2. 1992, 7; D. Pauković, n. d., 134-138; N. Barić, n. d., 169; M. Rupić, Dokumenti, IV, 150-152; М. Гулић, н. д., 334-335; S. Ružić, n. d., 58-59.

${ }^{30}$ Prvu pravu Vladu RSK su činili: mr Zdravko Zečević, predsjednik Vlade; Jovan Kablar, zamjenik predsjednika Vlade; Veljko Džakula, potpredsjednik Vlade; dr Boško Božanić, potpredsjednik Vlade; Stevo Bogić, potpredsjednik Vlade; Milan Martić, ministar unutrašnjih poslova; pukovnik Stojan Španović, ministar odbrane; Đorđe Bjegović, ministar energetike i rudarstva; Milan Knežević, ministar prosvjete; dr Dušan Jović, ministar zdravlja i zdravstvenog osiguranja; mr Vojin Šuša, ministar pravosuđa i uprave; Savan Grabundžija, ministar za saobraćaj i veze; mr Dušan Ećimović, ministar informisanja i mr Svetozar Vinčić, ministar trgovine i turizma. Za resore spoljnih poslova i finansija prvi ministar u tom trenutku nije imao odgovarajuća rješenja, pa su ta mjesta popunjena 21. marta, kada je za ministra finansija imenovan Vojin Peurača, a za ministra inostranih poslova Dobrosav Vejzović. S obzirom na to da je novim Zakonom o ministarstvima formirano više novih ministarstava, 18. maja izabrano je pet novih ministara: Mitar Brnović, ministar poljoprivrede, šumarstva i vodoprivrede; Sergej Veselinović, ministar kulture i vjera; David Rastović, ministar fizičke kulture i sporta; Rade Gaćeša, ministar za urbanizam, stambeno-komunalne poslove i građevinarstvo; i dr Mladen Hadžić, ministar za rad, boračka i socijalna pitanja. Posljednje ministarsko mjesto popunjeno je 28 . septembra 1992, kada je Nebojša Arbutina imenovan za ministra za ekonomske odnose, privredni razvoj i industriju. HMDCDR, 3-2, Odluka o izboru prvog ministra Vlade i ministara u Vladi RSK; Р. Суботић, С. Берић, „И нова влада остаје у Книну“, Поли- 
štinskog saziva, dužnost predsjednika Skupštine RSK obavlja dotadašnji predsjednik Skupštine SAO Krajine Mile Paspalj, dok su mjesta potpredsjednika zauzeli dotadašnji predsjednik Velike narodne skupštine SO Slavonija, Baranja i Zapadni Srem Ilija Končarević i dotadašnji predsjednik Narodne skupštine SAO Zapadna Slavonija Veljko Vukelić. ${ }^{31}$

Formiranjem Vlade Riste Matkovića 21. februara, a zatim Vlade Zdravka Zečevića 26. februara 1992. došlo je do paradoksalne situacije u kojoj su postojale „dvije vlade jednog naroda“. Vlada Zdravka Zečevića u prvim danima postojanja nije mogla ni da pomišlja da pokuša da se sastane u Kninu. Iako prestonica, Knin je bio i jedno od krajinskih opštinskih središta, a lokalna vlast je bila čvrsto u rukama Milana Babića. Vlada je, međutim, nastojala da se što više približi ,gradu pod Tvrđavom“, pa je 7. marta 1992. održala sjednicu u Golubiću, selu koje je udaljeno desetak kilometara od Knina i odakle je rodom zamjenik predsjednika Vlade i bivši predsjednik SO Knin Jovan Kablar. Vlada je donijela odluke o uvođenju privremenih mjera u Srpsku radio televiziju (SRT) Knin i formiranju JP Radio televizija Republike Srpske Krajine (RTRSK). Sa čelnog mjesta kninske televizije uklonjen je „Babićev kadar" Lazar Macura, a imenovan Branko Marjanović, odan novim vlastima. Planirano je da RTRSK dobije na upotrebu radio-relejne centre Ministarstva unutrašnjih poslova (MUP) na Promini, Ćelavcu, Plješevici, Petrovoj gori i Papuku. Tim potezima je trebalo iz ruku Milana Babića i njegovih pristalica preoteti televiziju, kao najvažniji medij toga vremena, i osigurati distribuciju programa državne televizije diljem RSK. Vlada je pokušala da preuzme i rukovođenje Predstavništvom RSK u Beogradu, pa je za novog šefa tzv. Biroa Krajine određen mr Slavko Prijić iz Knina. ${ }^{32}$ Dva dana kasnije Vlada Zdravka Zečevića je uspjela da održi prvu sjednicu u prestonici RSK. Dana 9. marta održana je sjednica u Domu armije u Kninu, što je imalo veliki simbolički značaj za nove krajinske vlasti. ${ }^{33}$

тика, 28. 2. 1992, 12; „Двије владе једног народа“, Српска Нова ријеч, 9. 3. 1992, 1; Чедо Кораћ, „Изабрана нова Влада“, „Нови састав Владе РСК“, Српски глас, 23. 3. 1992, 4; „Одлука о избору првог министра Владе Републике Српске Крајине“, „Одлука о избору министара у Влади Републике Српске Крајине“, Службени гласник Републике Српске Крајине, 22. 5. 1992, 716, 718; „Одлука о избору министра у Влади Републике Српске Крајине“, Службени гласник Републике Српске Крајине, 29. 9. 1992, 978-979; Јован Каблар, Сјећања: од Голубића до Београда (Београд: Удружење Срба из Хрватске, Удружење пензионера из Хрватске, Завичајно удружење Голубић, 2016), 298-300; S. Ružić, $n$. d., 62-66).

${ }^{31}$ HMDCDR, 3-2, Magnetofonske beleške sa sednice održane 26.02.1992. godine, u Borovu Selu; M. Rupić, Dokumenti, IV, 153-154; N. Barić, n. d., 169, 587-588; M. Гулић, н. д., 335-336.

${ }^{32}$ HMDCDR, 4-6, Druga sjednica Vlade RSK 07.03.1992, Golubić; HMDCDR, 4-6, Rješenje o postavljanju rukovodioca predstavništva RSK u Beogradu; M. Rupić, Dokumenti, IV, 159-160.

${ }^{33}$ HMDCDR, 4-6, Treća sjednica Vlade RSK 09.03.1992, Knin; M. Rupić, Dokumenti, IV, 160-161; S. Ružić, n. d., 53-54. 
Prvi put poslije izbora Vlade Zdravka Zečevića, Vlada Riste Matkovića je održala sjednicu 12. marta 1992. I ova sjednica je održana u zgradi SO Knin, a uz prvog ministra Matkovića, prisutni su bili ministri: Vaso Ležaić, Vukašin Babić, Lazar Macura, Dušan Badža, Drago Jaramaz, Petar Štikovac i Mićo Jelić Grnović, kao i načelnici okruga: Rajko Ležajić i Dušan Vještica. Predloženo je da Vlada ,poveća aktivnost“ izvan zemlje, sa namjerom da ,jasnije prikaže naš status u Jugoslaviji“. S tim u vezi, odlučeno je da se sa njenim stanovištima upoznaju EZ i UN, kojima su upućena pisma, sa zahtjevom da se poštuje pravo srpskog naroda na samoopredjeljenje. Vlada je usvojila: Zakon o sudskim taksama, Zakon o izdavanju publikacija, Zakon o tržišnoj inspekciji, Zakon o javnom informisanju, Zakon o kinematografiji, Statut Javnog preduzeća PTT saobraćaja Krajine, Statut Javnog preduzeća Elektroprivreda Krajine, Odluku o visini sredstava iz prometa prodaje naftnih derivata Javnog preduzeća za puteve Krajine i Tarifni sistem za prodaju električne energije. Kao svojevrsni odgovor na odluku Vlade Zdravka Zečevića, za novog šefa Biroa Krajine u Beogradu imenovan je ekonomista dr Časlav Ocić. Tada su određeni predsjednik i članovi Upravnog odbora Zavoda za zaštitu zdravlja Republike Srpska Krajina. ${ }^{34}$

Vlada Riste Matkovića nije imala zvaničnu komunikaciju ni sa kim. Međunarodna zajednica je nije priznavala kao predstavnika krajinskih Srba, mada se u početnom periodu njenog rada nije mnogo osvrtala ni na Vladu Zdravka Zečevića. Ono što je najvažnije, zvanični Beograd je potpuno ignorisao postojanje Vlade Riste Matkovića. Bilo kakva komunikacija tog tijela sa predstavnicima izvršnih vlasti u Beogradu nije bila moguća. O tome kako su vlasti Republike Srbije doživljavale Vladu blisku Milanu Babiću najbolje govori njihov odnos prema Birou Krajine u Beogradu. Pripadnici MUP-a Republike Srbije, prema usmenom naređenju ministra Zorana Sokolovića, upali su u prostorije Biroa Krajine 14. marta 1992. i uhapsile sekretara Zdenka Tošića, a Birou je onemogućen dalji rad. ${ }^{35}$

Uz podršku Beograda i držanje većeg dijela vlasti na terenu, Vlada Zdravka Zečevića je nastavila da preuzima i ono malo preostalih ingerencija koje je imao smijenjeni predsjednik Milan Babić. Nova sjednica Vlade RSK održana je u Domu armije u Kninu 17. marta. Tada su naglašeni problemi koje nova Vlada ima u preuzimanju kontrole nad najvažnijim medijem koji je još uvijek bio u rukama predsjednika SO Knin Milana Babića - Srpskim radio Kninom. ${ }^{36}$ Novu sjednicu Vlada RSK je održala 23. marta 1992. u Erdutu. Tada je donijeta odluka o formiranju JP Aerodrom Udbina. ${ }^{37} \mathrm{Na}$ sjednici Vlade u Kninu 7. aprila ovom Javnom preduzeću dodijeljen je i aerodrom u Zemuniku. Oba

\footnotetext{
${ }^{34}$ HMDCDR, 4-5, Zapisnik sa sjednice Vlade RSK, održane 12.03.1992. godine u zgradi opštine, soba broj 51; M. Rupić, Dokumenti, IV, 162-168; S. Ružić, n. d., 52-53.

${ }^{35}$ HMDCDR, 4-35, Br. 03-71/1-1992.

${ }^{36}$ HMDCDR, 4-6, Četvrta sjednica Vlade RSK 17.03.1992, Knin; M. Rupić, Dokumen$t i, \mathrm{IV}, 169-170$.

${ }^{37}$ HMDCDR, 4-5, Sedma sjednica Vlade RSK 23.03.1992, Erdut; M. Rupić, Dokumen$t i, \mathrm{IV}, 174$.
} 
aerodroma su u tom trenutku bila pod kontrolom Jugoslovenske narodne armije (JNA), ali se očekivalo da će, „nakon njenog preselenja iz RSK-a“, oni ,preći u nadležnost civilnim vlastima“. Za vršioca dužnosti direktora JP Aerodrom Udbina imenovan je Milan Džodan, a prvi civilni let sa aerodroma Udbina najavljen je za 15. april. Vlada je usvojila odluku o osnivanju JP Elektroprivreda Krajine, čime je načinjeno dvojstvo i u pogledu proizvodnje, prenosa i distribucije električne energije. Takođe, raspuštene su dotadašnje vlade u oblastima od kojih je sačinjena RSK. Umjesto toga, oblasti su mogle da imaju sekretarijate oblasnih vijeća, koji bi se sastojali od predsjednika, potpredsjednika i šest sekretara. Na taj način je Vlada Riste Matkovića negirana čak i kao oblasna vlada u SAO Krajini, što je jedino mogla da bude u takvom sastavu i odnosu snaga. ${ }^{38}$

Skoro mjesec dana nakon 28. sjednice, Vlada Riste Matkovića je 10. aprila 1992. održala 29., a vrijeme je pokazalo, i posljednju sjednicu. Osim prvog ministra Matkovića, prisutni su bili ministri: Vukašin Babić, Lazar Macura, Petar Stikovac, Jovan Katić, Vaso Ležaić i Dušan Badža, kao i načelnici okruga: Dušan Vještica i Rajko Ležajić. Uz članove Vlade bio je i predsjednik SO Knin i samozvani predsjednik RSK Milan Babić. Usvojena je Uredba o organizaciji i djelokrugu organizacionih jedinica Ministarstva unutrašnjih poslova, kojom je planirano postojanje tri resora: Resora nacionalne bezbjednosti, Resora javne bezbjednosti i Resora jedinica za posebne namjene, koji bi nosio ime Srpska nacionalna garda. Takođe, usvojeni su Uredba o zvanjima i ovlaštenjima službenih lica organa Unutrašnjih poslova i o zvanjima radnika Ministarstva unutrašnjih poslova Republike Srpska Krajina, kao i Pravilnik o disciplinskoj i materijalnoj odgovornosti radnika Ministarstva unutrašnjih poslova Republike Srpska Krajina. Možda bi svi ovi propisi imali neki značaj da je Vlada Riste Matkovića uopšte kontrolisala policiju u Krajini. Vlada je usvojila zahtjev JP Elektrokrajina da se poveća cijena električne energije za 182\%, pošto se, kako je ukazao ministar Vukašin Babić, „ne može poslovati s postojećim cijenama električne energije“. Budući da je Vlada odlučivala o postavljenju sudije za prekršaje u Vrginmostu, a na prijedlog SO Vrginmost, kao i o zahtjevu Savjeta SO Pakrac za dodjelu novčane pomoći, čini se da su, osim Knina, još samo te dvije opštine imale neke veze sa Vladom Riste Matkovića. ${ }^{39}$

Vlada Riste Matkovića je toga dana usvojila zaključak da se Službi društvenog knjigovodstva (SDK) Republike Srbije uputi oštar protest zato što joj je onemogućila bilo kakav pristup sredstvima budžeta RSK. Zabrana pristupa sredstvima budžeta predstavljala je konačan udarac za paralelnu Vladu Riste Matkovića. Nakon toga ona više nije raspolagala ni sa čim. Zbog toga je bila primorana da odbije zahtjev iz Pakraca za dodjelu finansijske pomoći, nije mogla da izvrši uplatu korisnicima sredstava boračko-invalidske zaštite, kao ni da podmiri dugovanja Jadrantransu za prevoz učenika na teritoriji SO Knin. Vlada je počela da se osipa, pa je poslije Savana Grabundžije, koji je dobio resor u Vladi Zdravka Ze-

${ }^{38}$ HMDCDR, 4-5, Osma sjednica Vlade RSK 07.04.1992, Knin; M. Rupić, Dokumenti, IV, 195-202.

${ }^{39}$ HMDCDR, 4-5, Zapisnik sa 29. sjednice Vlade RSK, održane 10.4.1992. godine, u zgradi Opštine, soba br. 51; M. Rupić, Dokumenti, IV, 202-207; S. Ružić, n. d., 50. 
čevića i nije bio prisutan ni na jednoj sjednici Vlade Riste Matkovića, na prijedlog Milana Babića, sa mjesta ministra unutrašnjih poslova razriješen Slavko Ožegović. Odlučeno je da će prvi ministar voditi taj resor do izbora novog ministra. Bez obzira na teške udarce koje je doživjela, Vlada Riste Matkovića je i dalje pokušala da kadrira, pa je izabrala predsjednika i članove Upravnog odbora JP PTT saobraćaja, a donijela je i Zakon o vršenju javnih ovlašćenja i načinu obezbjeđenja sredstava Crvenog krsta Srpska Krajina. ${ }^{40}$

Vlada kojom je rukovodio Zdravko Zečević uopšte se više nije osvrtala na djelovanje i odluke koje je donosila Vlada Riste Matkovića, koja je jednostavno nazivana „,bivšom“. Ona je zasjedala i radila kako je smatrala da treba. Na sjednici u Kninu 14. aprila 1992. donijeta je odluka o izboru članova Upravnog odbora Zavoda za zaštitu zdravlja i Upravnog odbora Zavoda za zdravstveno osiguranje. Dva dana kasnije, 16. aprila nailazimo na posljednji datirani akt Vlade Riste Matkovića. Radilo se o slanju na štampanje i objavljivanje zakonskih propisa i drugih akata u Glasniku Krajine, dotadašnjem službenom glasilu SAO Krajine. Međutim, ništa od toga nije objavljeno, pošto Glasnika Krajine više nije bilo, a njegovo mjesto je zauzeo Službeni glasnik Republike Srpske Krajine. ${ }^{41}$

Tih dana je određeni uticaj Vlada Riste Matkovića imala samo u prosvjeti i zdravstvu. Ministar prosvjete Milan Knežević je u razgovoru sa direktorima škola sa kninskog, benkovačkog, obrovačkog i gračačkog područja saznao sa kojim poteškoćama se suočavaju obrazovne ustanove, među kojima je najveći bilo finansiranje. Spominjao se „Ristin fond“ iz koga su sredstva dijeljena tako da „ko je uz Ristu dobiće plaću, inače plaće nema“. U domenu zdravstva „ministar“ Vaso Ležaić je imao veliki uticaj u Zdravstvenom centru u Kninu, koji je predstavljao najveću i najvažniju zdravstvenu ustanovu u RSK. Kako bi se i taj uticaj suzbio, na sjednici Vlade RSK zaduženi su ministri zdravlja i zdravstvenog osiguranja Dušan Jović i prosvjete Milan Knežević da od svojih prethodnika Vase Ležaića i Miće Jelića Grnovića zahtijevaju da vrate službene pečate. Ukoliko oni odbiju da to urade, trebalo je obavijestiti MUP, „koji bi im te predmete oduzeo po službenoj dužnosti““. 42

Dvojstvo krajinskih vlada prekinuli su vanredni događaji, koji su dodatno zakomplikovali prilike na jugoslovenskom prostoru. Tokom aprila 1992. rasplamsao se Građanski rat u BiH, koji se u značajnoj mjeri odrazio i na područje RSK, ponajviše prekidom saobraćajnih veza između Krajine i Srbije. Osim toga, 27. aprila 1992. u Beogradu je svečano proglašena Savezna Republika Jugoslavija (SRJ), kao treća jugoslovenska država, koju su sačinjavale samo Srbija i Crna Gora, čime je Krajina definitivno prestala da bude sastavni

${ }^{40}$ HMDCDR, 4-5, Zapisnik sa 29. sjednice Vlade RSK, održane 10.4.1992, u zgradi Opštine, soba br. 51; HMDCDR, 4-35, Br. 03-84/1-92; HMDCDR, 4-35, Br. 03100/1-92; M. Rupić, Dokumenti, IV, 202-207; S. Ružić, $n$. d., 52.

41 HMDCDR, 4-6, Deveta sjednica Vlade RSK 14.04.1992, Knin; M. Rupić, Dokumenti, IV, 208-216.

42 HMDCDR, 4-6, Deseta sjednica Vlade RSK 21.04.1992, Knin; M. Rupić, Dokumenti, IV, 208-216, 221-230. 
dio jugoslovenske države. Vlada RSK koju je predvodio Zdravko Zečević nastavila je da održava sjednice u Domu JNA u Kninu ili Domu privrednika na Kninskoj tvrđavi, suočavajući se sa mnogo većim izazovima i ozbiljnijim problemima nego što su to bili stavovi Milana Babića ili Riste Matkovića. Njihova struja je, iako poražena, nastavila da vodi glavnu riječ u opštinskoj vlasti u Kninu, dok je ostatak Krajine bio prevelik zalogaj za sve krajinske političare koji nisu pokorno slušali ono što Beograd kaže.

\section{REFERENCE}

- Barić, Nikica. Srpska pobuna u Hrvatskoj 1990.-1995. Zagreb: Golden marketing, Tehnička knjiga, 2005.

- Gulić, Milan. „Proglašenje Republike Srpske Krajine: u sjenci Vensovog plana“. U: Građanski rat u Hrvatskoj 1991-1995, XI-XII. Urednik Milojko Budimir, 274-337. Beograd: Udruženje Srba iz Hrvatske, Srpsko kulturno društvo Zora, Srpska čitaonica Dr Jovan Rašković, 2016.

- Kablar, Jovan. Sjećanja: od Golubića do Beograda. Beograd: Udruženje Srba iz Hrvatske, Udruženje penzionera iz Hrvatske, Zavičajno udruženje Golubić, 2016.

- Miškulin, Ivica. „Republika Hrvatska i mirovna operacija Ujedinjenih naroda: kada, kako i zašto je došlo do njezine realizacije?“. Historijski zbornik, LXIV, br. 1, (2011), 121-159.

- Mladineo, Goran, ur. Tuđmanov arhiv. Korespondencija predsjednika Republike Hrvatske dr. Franje Tuđmana od 1990. do 1999. godine, I, Godine stvaranja i obrane: 1990.-1991. Zagreb: Hrvatska sveučilišna naklada, Hrvatski institut za povijest, 2015.

- Paspalj, Mile. Album iz Krajine. Sarajevo: MNIPT Javnost, 1996.

- Paspalj, Mile. Razotkrivanje istine. Beograd: Kulturna zajednica Krajine, 2015.

- Pauković, Davor, prir. Uspon i pad „Republike Srpske Krajine“. Dokumentarni kronološki prikaz nastanka i propasti paradržave. Zagreb: Centar za politološka istraživanja, 2005.

- Radulović, Srđan. Sudbina Krajine. Beograd: Dan graf, 1996.

- Rupić, Mate, ur. Republika Hrvatska i Domovinski rat 1990.-1995. Dokumenti, II, Dokumenti institucija pobunjenih Srba u Republici Hrvatskoj (1990.1991.). Zagreb: Hrvatski memorijalno-dokumentacijski centar Domovinskog rata, Slavonski Brod: Hrvatski institut za povijest - Podružnica za povijest Slavonije, Srijema i Baranje, 2007.

- Rupić, Mate, ur. Republika Hrvatska i Domovinski rat 1990.-1995. Dokumenti, IV, Dokumenti institucija pobunjenih Srba u Republici Hrvatskoj (siječanjlipanj 1992). Zagreb: Hrvatski memorijalno-dokumentacijski centar Domovinskog rata, Slavonski Brod: Hrvatski institut za povijest - Podružnica za povijest Slavonije, Srijema i Baranje, 2008.

- Ružić, Slaven. Djelovanje „Vlade Republike Srpske Krajine“ 1991.-1995. Zagreb: Hrvatski memorijalno-dokumentacijski centar Domovinskog rata, 2017. 
- Stojković, Momir, prir. Balkanski ugovorni odnosi 1876-1996. Dvostrani i višestrani međunarodni ugovori i drugi diplomatski akti o državnim granica$m a$, političkoj $i$ vojnoj saradnji, verskim $i$ etničkim manjinama, III (19461996). Beograd: Službeni list SRJ, Međunarodna politika, 1999.

- Šušić Slavoljub, Zlatoje Terzić i Nikola Petrović, prir. Zbornik dokumenata iz oblasti odbrane i bezbednosti Jugoslavije 1990-1991. godine. Beograd: Generalštab Vojske Jugoslavije, Sektor za školstvo, obuku, naučnu i izdavačku delatnost, Uprava za naučnu i izdavačku delatnost, 2002.

MILAN GULIĆ, PhD, Senior Research Associate

Institute for Contemporary History

Belgrade, Republic of Serbia

milan.gulic@gmail.com

\author{
PARALLEL GOVERNMENT OF RISTO MATKOVIĆ (1992). \\ CONTRIBUTION TO THE STUDY OF POLITICAL CONFLICTS \\ IN THE REPUBLIC OF SERBIAN KRAJINA
}

\title{
Summary
}

In early 1992, there was a conflict between Knin and Belgrade over the acceptance of the Vance plan. The conflict also affected relations on the political scene of the Republic of Serbian Krajina. There was a split into two factions. One was headed by President Milan Babić, who was against the Vance plan, and the other was Parliament Speaker Mile Paspalj, who under pressure from Belgrade accepted the plan. In those conflicts, there was a parallelism of power, so during February, March, and April of 1992, the Krajina had two governments. The focus of this paper is on the parallel government whose first minister was Risto Matković. His government was loyal to Milan Babić and had no significant support outside Knin. It held only three sessions and tried to counter the Government of Zdravko Zečević, which had the support of the Parliament of the Republic of Serbian Krajina and of official Belgrade, which was a crucial moment in the exercise of political power in the Krajina throughout its existence. The paper is based on unreleased archival materials, published documents, press, memoirs, and professional literature.

KEYWORDS: Risto Matković, Republic of Serbian Krajina, Government of the Republic of Serbian Krajina, Parliament of the Republic of Serbian Krajina, Milan Babić, Mile Paspalj 